\title{
ĐÁNH GIÁ BỀ DÀY VÁCH XƯƠNG VÀ MÔ NƯỚU MĂT NGOÀI VÙNG RĂNG TRƯớC HÀM TRÊN: NGHIÊN CỨU TRÊN Hİ̀NH ẢNH CBCT
}

\author{
Trần Hùng Lâm*, Đoàn Vũ **, Trần Ngọc Quảng Phi*
}

TÓM TẮT

Mục tiêu: xác định bề dày vách xương mặt ngoài, bề dày mô nướu mặt ngoài nhóm răng trước hàm trên của 100 bệnh nhân có chỉ định thực hiện CBCT.Phương pháp nghiên cứu: nghiên cứu cắt ngang mô tả thực hiện trên 100 hình ảnh CBCT thoả mãn các tiêu chí chọn mẫu. Bề dày vách xương mắt ngoài của răng trước hàm trên được đo đạc trong mặt cắt đứng dọc tai các vi trí cách mào xương $1 \mathrm{~mm}$ (điểm $A), 3 \mathrm{~mm}$ (điểm $B$ ), $5 \mathrm{~mm}$ (điểm $C$ ) và tại chóp răng. Bề dày mô nướuchỉ được đo tại điểm $A$. Kết quá: bề dày vách xương mặt ngoài (mm)tương ứng các răng trước hàm trên như sau: răng cửa giữa: tai A là $0,76 \pm 0,24$, tại $B$ là $0,69 \pm 0,23$, tại $C$ là $0,60 \pm$ 0,24 , tại chóp răng là $1,63 \pm 0,93$; răng cửa bên: tại $A$ là $0,79 \pm 0,29$, tại $B$ là $0,61 \pm 0,44$, tại $C$ là $0,27 \pm$ 0,31 , tại chóp răng là $1,77 \pm 0,94$; răng nanh: tại $A$ là $0,83 \pm 0,39$, tại $B$ là $0,71 \pm 0,46$, tại $C$ là $0,42 \pm 0,34$, tại chóp răng là $1,60 \pm 0,79$. Bề dày mô nướu mắt ngoài tại điểm A: răng cửa giữa: $0,76 \pm 0,19$;răng cửa bên: $0,59 \pm 0,19$; răng nanh: $0,53 \pm 0,19$. Kết luận: hầu hết bệnh nhân $(84,6 \%)$ có vách xương và mô nướu mặt ngoài mỏng hớn $1 \mathrm{~mm}$.

Tư khoá: Vách xương mặt ngoài, mô nướu mặt ngoài, CBCT

\section{SUMMARY}

EVALUATION THE THICKNESS OF ANTERIOR FACIAL GINGIVA AND

ALVEOLAR BONE PLATE ON CBCT IMAGES

Objectives: Tomeasure the thickness of facial bone wall and facial gingiva at teeth in the anterior maxilla based on CBCT of 100 patients. Methods:this descriptive cross-sectional study was realized on 100 CBCT fulfilling all inclusion criteria. The thickness of facial bone wall at teeth in the anterior maxilla was measured in the sagittal sectionat $1 \mathrm{~mm}$ from crestal level (point A), 3mm from crestal level (point B), $5 \mathrm{~mm}$ from crestal level and at the apex. The thickness of facial gingival was measuredonly at point A. Results: the thickness of facial bone wall (in $\mathrm{mm}$ ) of central incisor: at point $A$ is $0,76 \pm 0,24$, at point $B$ is $0,69 \pm$ 0,23 , at point $C$ is $0,60 \pm 0,24$, at the apex is $1,63 \pm$ 0,93 ; of lateral incisor: at point $A$ is $0,79 \pm 0,29$, at point $B$ is $0,61 \pm 0,44$, at point $C$ is $0,27 \pm 0,31$, at the apex is $1,77 \pm 0,94$; of canine: at point $A$ is 0,83 $\pm 0,39$, at point $B$ is $0,71 \pm 0,46$, at point $C$ is $0,42 \pm$ 0,34 , at the apex is $1,60 \pm 0,79$. The thickness of

\footnotetext{
*Trường Đai hoc Văn Lang

**Dr Care Implant Clinic

Chịu trách nhiệm chính: Trần Ngọc Quảng Phi

Email: phi.tnq@vuu.edu.vn

Ngày nhận bài: 3/2/2021

Ngày phản biện khoa học: 23/2/2021

Ngày duyệt bài: 14/3/2021
}

facial gingiva at point $A$ : of central incisor is $0,76 \pm$ 0,19 ; of lateral incisor is $0,59 \pm 0,19$; of canine is 0,53 $\pm 0,19$. Conclusion: most of the patients present the facial bone plate and facial gingiva inferior of $1 \mathrm{~mm}$.

Keywords: Facial bone plate, facial gingiva, CBCT

\section{I. ĐĂT VẤN ĐỀ}

Trong thực hành Nha khoa, mô nướu và vách xương măt ngoài vùng răng trước hàm trên là thành phần quan trọng quyết định sự thành công về thẩm mỹ của điêuu trị. Đây là phần "thẩm mỹ hồng" của kết quả điều trị. Để đảm bảo mô nướu lành manh cần mô xương nâng đõ tốt. Tuy nhiên, để đạt được điều này không phải dễ dàng vì vách xướng mặt ngoài rất nhạy cảm đối với các bệnh lý như viêm nha chu, nhiễm trùng quanh chóp răng, $u$ nang xương hàm hay các điêuu trị nha khoa như nhổ răng, chỉnh nha, cấy ghép nha khoa.

Cây ghép nha khoa (Implant) là một trong những điều trị có liên quan đặc biệt đến mô nướu và xương mặt ngoài vùng răng trước hàm trên. Implant đã và đang phát triển trong hơn 50 năm gần đây, dần trở thành lựa chọn tối ưu trong nhiêu trường hợp phục hồi răng mất nhằm tái tạo lại răng giả có chức năng và sinh lý gần giống với răng thật nhất. Thế nhưng, quá trình phục hồi vùng răng trước hàm trên thực sự là thách thức với các nhà lâm sàng nhằm đạt mục tiêu tạo lại mô mềm quanh implant gần như răng thật với màu sắc lành mạnh, đủ bề dày bao phủ implant, bảo tồn gai nướu cũng như mức nướu viền. Bởi vì, dù đã được đề cập đến khá nhiều trong y văn, nhưng tổn thương của mô nướu và vách xương ngoài vùng răng trước hàm trên vẫn là những biến chứng thường gặp. Các biến chứng này gây nên những khiếm khuyết về thẩm mỹ cũng như sự không hài lòng của bệnh nhân dẫn đến thất bại của điều trị.

Do đó, đã có nhiều nghiên cứu trên thế giới khảo sát những đặc điểm giải phẫu vùng răng trước hàm trên bao gồm mô nướu, mô xương, hình thái chân răng trước trong xương ổ... với mong muốn tạo ra một bộ dữ liệu cơ sở về vùng giải phẫu quan trọng này, nhẳm giúp các nhà lâm sàng đưa ra chỉ định hợp lý nhất khi thực hành implant. Trong những nghiên cứu này, phương tiện được dùng chủ yếu là Hình ảnh cắt lớp điện toán sử dụng tia chùm nón (CBCT). Đây là công cụ tốt nhất hiện nay để khảo sát mô 
cứng vùng giải phẫu liên quan trong lĩnh vực nha khoa, theo 3 chiều trong không gian với ưu điểm cho hình ảnh rõ nét, độ biến dạng tối thiểu, kỹ thuật ít xâm lấn [1].

Năm 2010, Menezes và Jason cho thây công cụ đo đạc trên CBCT có độ chính xác cao khi khảo sát bề dày vách xương ổ răng mặt ngoài và mặt trong. Năm 2008, Januário đề nghị dùng CBCT để đo các chỉ số mô mềm thuộc đơn vi răng nướu như khoảng cách từ viền nướu tới mào xương, từ viền nướu tới đường nối men xê măng, bề dày mô nướu[5]. So với các phương pháp cũ là đo xuyên nướu, và sử dụng sóng siêu âm thì phương pháp mới cho kết quả chính xác tương tự. Tuy nhiên, cho đến nay số nghiên cứu dùng $C B C T$ để đo bề dày mô nướu mặt ngoài còn hạn chế[5].

Bên cạnh đó, kết quả giữa các nghiên cứu về hình thái xương và mô nướu có sự khác biệt do phương pháp nghiên cứu, cách chọn mẫu, và trên hết là đặc điểm chủng tộc khác nhau. Tại Việt Nam, hiện nay chưa có nghiên cứu nào về đặc điểm hình thái vách xương và mô nướu mặt ngoài vùng răng trước hàm trên sử dụng $\mathrm{CBCT}$ được công bố.

Với những lý do nêu trên, chúng tôi thực hiện đề tài nghiên cứu " Đánh giá bề dày vách xương và mô nướu mă̆t ngoài vùng răng trước hàm trên: Nghiên cứu trên CBCT " với mục tiêu nghiên cứu: Xác định bề dày vách xương mặt ngoài và bề dày mô nướu mặt ngoài nhóm răng trước hàm trên.

\section{II. ĐỐI TƯợNG VÀ PHƯƠNG PHÁP NGHIÊN CỨU}

\section{KẾT QUẢ NGHIÊN CỨU}

3.1. Bề dày vách xương mặt ngoài. Ở cả 3 nhóm răng, bề dày vách xương mặt ngoài có giá trị lớn nhất ở $A$, giảm dần ở $B$ và $C(p<0,001)$.

Bảng 1: Bề dày (mm) vách xương mặt ngoài răng trước hàm trên đo tại $A, B, C$ và $A P$

\begin{tabular}{|c|c|c|c|c|c|c|c|c|c|c|c|c|}
\hline & \multicolumn{4}{|c|}{ Răng cửa giữa (n=200) } & \multicolumn{2}{c|}{ Răng cửa bên (n=200) } & \multicolumn{3}{c|}{ Răng nanh (n=200) } \\
\hline & $\mathrm{BA}$ & $\mathrm{BB}$ & $\mathrm{BC}$ & $\mathrm{BAP}$ & $\mathrm{BA}$ & $\mathrm{BB}$ & $\mathrm{BC}$ & $\mathrm{BAP}$ & $\mathrm{BA}$ & $\mathrm{BB}$ & $\mathrm{BC}$ & $\mathrm{BAP}$ \\
\hline Trung bình & 0,76 & 0,69 & 0,60 & 1,63 & 0,79 & 0,61 & 0,27 & 1,77 & 0,83 & 0,71 & 0,42 & 1,60 \\
\hline Độ lệch chuấn & 0,24 & 0,23 & 0,24 & 0,93 & 0,29 & 0,44 & 0,31 & 0,94 & 0,39 & 0,46 & 0,34 & 0,79 \\
\hline Trung vị & 0,70 & 0,70 & 0,50 & 1,50 & 0,70 & 0,50 & 0,30 & 1,55 & 0,70 & 0,60 & 0,40 & 1,45 \\
\hline Giá trị lớn nhất & 1,9 & 1,6 & 1,5 & 5,5 & 1,8 & 2,7 & 1,5 & 5,2 & 2,7 & 2,7 & 1,9 & 4,7 \\
\hline Giá trị nhỏ nhất & 0,3 & 0,2 & 0 & 0 & 0,3 & 0 & 0 & 0 & 0 & 0 & 0 & 0 \\
\hline
\end{tabular}

Kiểm định Friedman, kiểm định Wilcoxon

Bề dày xương trung bình tại chóp răng (BAP) ở răng cửa bên $(1,77)$ lớn hớn so với răng cửa giữa $(1,63)$ và răng nanh $(1,60)$ với khác biệt có ý nghĩa $(\mathrm{p}<0,01)$. Trong khi đó, BAP ở răng cửa giữa và răng nanh không có sự khác biệt có ý nghĩa $(p>0,05)$.
Nghiên cứu cắt ngang mô tả thực hiện trên hình ảnh $100 \mathrm{CBCT}$ người Việt Nam trưởng thành với các điều kiện: không mất răng ở vùng răng trước (từ răng 13 đến 23), các răng khảo sát không có bệnh lý nha chu hay nhiễm trùng chóp, ảnh hưởng đến việc đánh giá vách xương và mô mềm mặt ngoài. Tất cả các phim CBCT đều chụp bằng máy $\mathrm{CBCT}$ Picasso Trio (Ewoo Vatech Hàn quốc) bởi cùng một kỹ thuật viên đã được huấn luyện định chuẩn. Ứng viên trước khi chụp được đặt 2 thanh gòn cuộn sát đáy hành lang phía trước hàm trên, ở 2 bên và ngay cạnh thắng môi trên nhằm phân cách mô mềm. Tiến hành vẽ và đo đạc trong mặt cắt đứng dọc (độ phóng đại 7 lần): Đo bề dày xương $(B A)$ và bể dày nướu (GA) tại $A$ cách mào xương $1 \mathrm{~mm}$; đo bề dày xương $(B B)$ tại $B$ cách mào xương $3 \mathrm{~mm}$; đo bề dày xương $(\mathrm{BC})$ tại $C$ cách mào xương 5 $\mathrm{mm}$ và đo bề dày xương tại chóp răng (BAP). Trường hợp răng có vùng nứt xương kéo dài đến 1/3 chóp răng hoặc không có xương mặt ngoài, nhưng vẫn còn mổ nướu mặt ngoài thì điểm $A$ sẽ được định vị cách viền nướu $4 \mathrm{~mm}$ để đo bề dày mô nướu. Xử lý số liệu được thực hiện với phần mềm Excel 2010 và SPSS 18.0 (PASW Statistic 18).

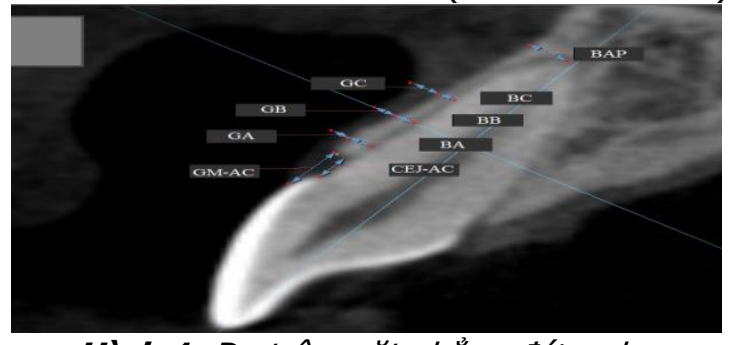

Hình 1. Đo trên mặt phẳng đứng dọc 


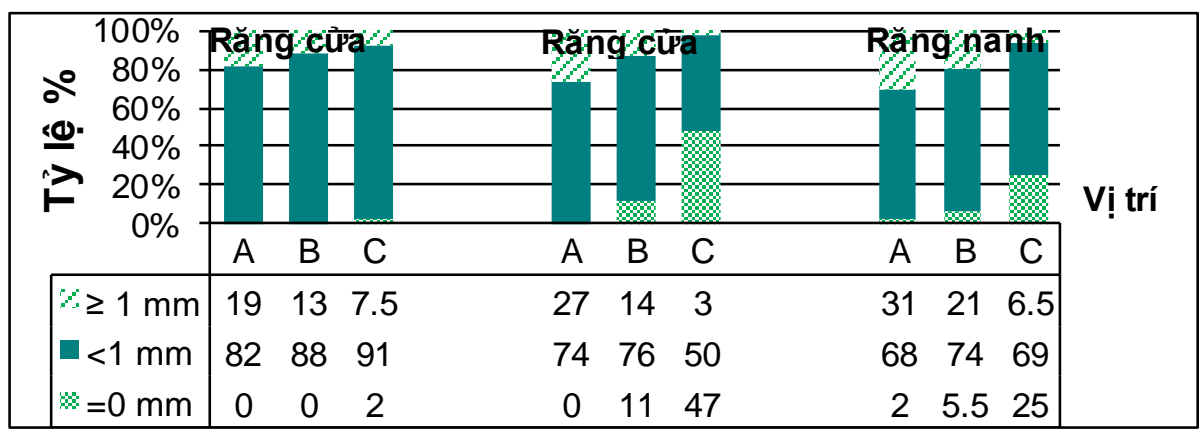

Biểu đồ 1: Tỷ lệ (\%) phân bố bề dày vách xương mặt ngoài tại các vị trí $A, B, C$ của mỗi nhóm răng

3.2. Bề dày mô nướu mặt ngoài. Do bề rộng nướu sừng hoá vùng răng trước hàm trên ở người Việt trung bình 4,08 $1,05 \mathrm{~mm}$ (Nguyễn Meo, 2007) nên chúng tôi chỉ đo bề dày mô nướu tại $A$ (cách mào xương ổ răng $1 \mathrm{~mm}$ về phía chóp). Xét tại điểm $A$, mô nướu của răng cửa giữa là dày nhất $(0,76 \pm 0,19)$ tiếp đến là răng cửa bên $(0,59 \pm 0,19)$ và mỏng nhất là răng nanh $(0,53 \pm 0,19)$, sự khác biệt này có ý nghĩa thống kê $(p<0,01)$.

\section{BÀN LUÂN}

Nghiên cứu được thực hiên trên 100 ứng viên, có chỉ định chụp $\mathrm{CBCT}$, từ 18 tuổi trở lên, đây được xem là độ tuổi có xương gần như hoàn thiện, thích hợp để nghiên cứu.

Chúng tôi muốn đề xuất một kỹ thuật mới để khi chụp CBCT để có thể thây rõ mô mềm mặt ngoài vùng răng trước là đặt gòn cuộn ở ngách hành lang măat ngoài trước khi chụp. Phương pháp này tương tự như đề xuất dùng banh môi của Janúario (2008), có thể thấy mô mềm mặt ngoài hầu hết răng hàm trên và hàm dưới [5], nhưng dùng gòn cuộn cũng rất hiệu quả khi muốn quan sát mô mềm vùng răng trước, ngoài ra cách làm đơn giản hơn cho kỹ thuật viên chụp CBCT và dễ chịu cho bệnh nhân hơn. Bên cạnh đó, gòn chỉ sử dụng 1 lần điều này giảm được khâu sát khuẩn khi thực hiện. Các chỉ định chụp CBCT sau này có thể tùy tình huống mà áp dụng một trong hai phương pháp $\mathrm{CBCT}$ mô mềm như trên.

Trong nghiên cứu này, giá trị trung bình bề dày vách xương khi đo ở 3 điểm $A, B, C$ mặt ngoài ở răng cửa giữa từ 0,60 đến 0,76 ; khoảng biến thiên này nhỏ hơn so với khi đo ở răng nanh từ 0,42 đến 0,83 và răng cửa bên từ 0,27 đến 0,79 . Khi so sánh với nghiên cứu của Januário (2011) [3] đo 250 CBCT bệnh nhân Brazil và nghiên cứu của Zerky (2012) [6] đo 200 CBCT bệnh nhân Châu Á. Đây là hai trong số các nghiên cứu có cùng tiêu chí chọn mẫu và phương pháp đo tương tự với nghiên cứu của chúng tôi. Kết quả bề dày vách xương mặt ngoài vùng răng trước trong nghiên cứu của chúng tôi cao hơn nghiên cứu của Januário và thấp hơn nghiên cứu của Zerky. Điều này được lý giải do sự khác nhau tính đặc thù của mỗi chủng tộc. Do đó có thể nói người Việt có đặc điểm xương ổ răng không giống những quốc gia khác ở Châu Á nói riêng và trên cả thể giới nói chung.

Thật vậy, số đo trong kết quả nghiên cứu của chúng tôi ít tương đồng với các nghiên cứu được thực hiện ở nhiều nơi trên thế giới (Biểu đồ2)

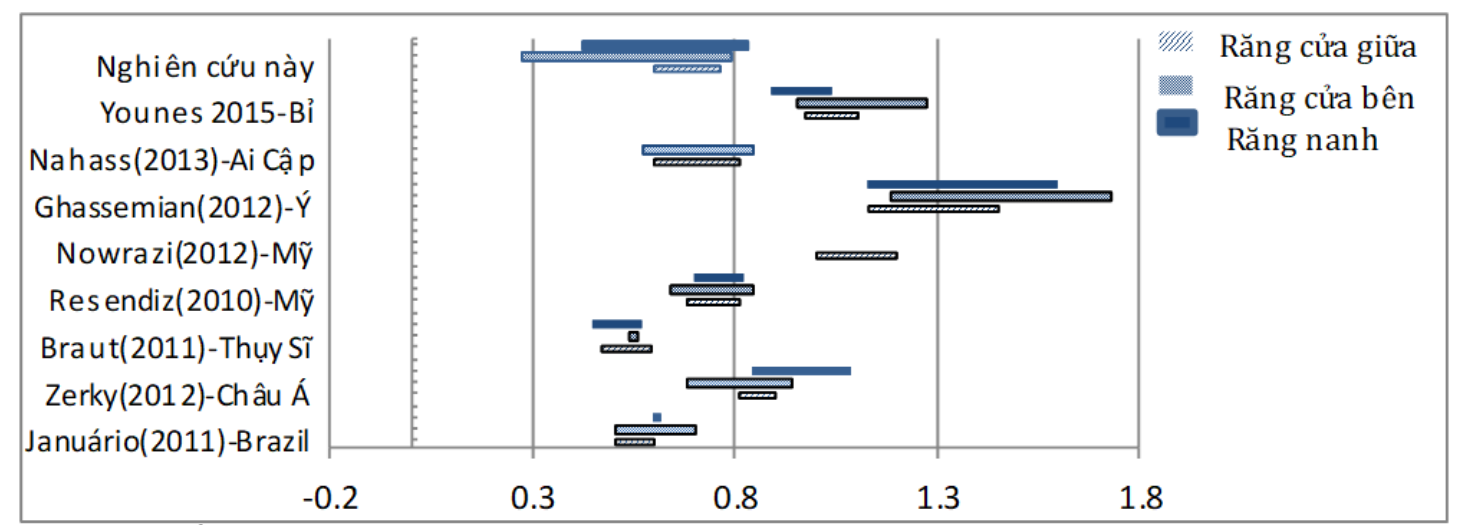

Biểu đồ 1. So sánh độ biến thiên bề dày $(\mathrm{mm})$ vách xương mặt ngoài với các nghiên cứu khác 
Xương măt ngoài dày ở vị trí $A$, và mỏng hơn ở vịtrí $\mathrm{B}$ và $\mathrm{C}$. Tỷ lệ xuất hiện cửa sổ xương (không có xương ở $B$ và $C$ ) tập trung cao nhất ở răng cửa bên đến $58 \%$. Kết quả này trùng khớp với nghiên cứu của Zekry (2012) [6] là 58,8\% cũng ở người châu Á. Trong các nghiên cứu trên người Caucasian trước đó, tỷ lệ có cửa sổ xương cao nhất chỉ là 21,3\%[4], tập trung nhiều ở răng nanh và răng cửa giữa hơn răng cửa bên [5]. Sự khác biệt này ít nhiêu có thể do phương pháp đo giữa các nghiên cứu với vị trí đo khác nhau. Nhưng có thể khẳng định sự khác biệt về bề dày vách xương ổ răng mặt ngoài của ngườI châu $A$ và người Caucasian. Theo Grunder và cs (2005), khi đặt implant bề dày xương mặt ngoài tại điểm A từ $2 \mathrm{~mm}$ trở lên sẽ đảm bảo sự ổn định lâu dài về mặt thẩm mỹ [8]. Trong nghiên cứu này, ở tất cả vị trí đo, bề dày xương từ $2 \mathrm{~mm}$ trở lên chiếm tỉ lệ rất ít $(0-3 \%)$. Kết quả này giống các nghiên cứu tương tự khác đã công bố [7]. Rõ ràng, bênh nhân có bề dày xương từ $2 \mathrm{~mm}$ trở lên như mong muốn của các nhà lâm sàng implant rất ít cho dù là dân tộc nào trên thế giới.

Căn cứ vào hệ thống phân loại hình dạng vách xương mặt ngoài của Mandelaris và cs năm 2013 [8], khi đánh giá các răng trong nghiên cứu của chúng tôi, bề dày vách xương mặt ngoài dưới $1 \mathrm{~mm}$ chiếm 84,6\% (Biểu đồ 3 ). Và loại xương chiếm tỉ lệ cao ở đây là dạng "mỏng / mỏng"; tức là bề dày vách răng mặt ngoài tại mào xương ổ răng mỏng và tại xương ổ răng quanh chân răng mỏng. Kết quả này tương tự Braut (2011) khi đo đạc trên CBCT bệnh nhân Thụy Sỹ [2].

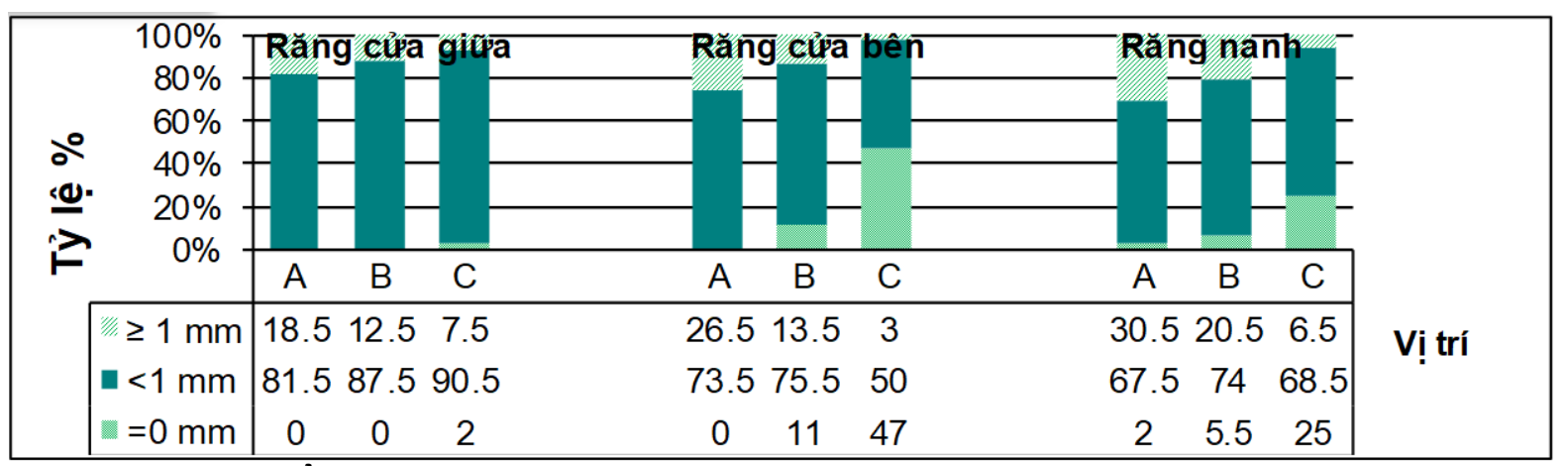

Biểu đồ 3. Tỷ lệ (\%) phân bố bề dày vách xương mặt ngoài tại

\section{các vị trí $A, B, C$ của mối nhóm răng}

Dang xương mỏng này là thách thức lớn mà các nhà lâm sàng găp phải khi có kế hoach can thiệp ở vùng răng thẩm mỹ. Đây có thể là một trong những nguyên nhân gây ra tỉ lệ tụt mô mêm khá cao sau khi đặt implant tức thì vào ổ nhổ răng. Khi còn răng, vách xương mă̆t ngoài được nuôi dưỡng phân lớn từ mạch máu từ dây chẳng nha chu nên khi răng mất đi vách xương ngoài sẽ bị tiêu đi bất kể có áp dụng phương pháp bảo tồn nào, vách xương càng mỏng sự tiêu đi sau nhổ răng càng nhiều, thậm chí dẫn đến mất hoàn toàn vách xương mặt ngoài. Đây cũng là nguyên nhân cản trở điều trị chỉnh hỉnh đạt kết quả lý tưởng về chức năng, thẩm mỹ, đặc biệt ở những trường hợp bệnh nhân có hệ xương đã trưởng thành. Những trường hợp này cần kết hợp với chỉnh hình tăng tạo xương quanh răng hay chỉnh hình có hỗ trợ phẫu thuật để đạt kết quả tối ưu.

\section{KẾT LUÂN}

Đặc điểm bề dày vách xương mặt ngoài răng trước hàm trên đa số thuộc loại mỏng (dưới
$1 \mathrm{~mm}$ ), chiếm tỉ lê $84,6 \%$. Trong các răng trước, bề dày xương mă̆t ngoài mỏng nhất ở răng nanh và trên mỗi răng, vách xương dày nhất tương ứng vị trí điểm $A$ (cách mào xương $1 \mathrm{~mm}$ ).

Đắc điểm mô nướu mă̆t ngoài mỏng hơn $1 \mathrm{~mm} c h i e ̂ ́ m$ đa số $(84,6 \%)$, trong đó, nướu măt ngoài dày nhất ở răng cửa giữa và mỏng nhất ở răng nanh.

\section{TÀI LIÊU THAM KHẢO}

1. Braut V., Bornstein M. M., Belser U., Buser D. (2011), "Thickness of the anteriormaxillary facial bone wall-a retrospective radiographic study using cone beamcomputedtomography", Int J Periodontics Restorative Dent, 31(2), pp.125-131.

2. Nowzari H., Molayem S., Chiu C. H. K., Rich S.K. (2012), "Cone beam computedtomographic measurement of maxillary central incisors to determine prevalence of facialalveolar bone width $\geq 2 \mathrm{~mm}$ ", Clinical implant dentistry and related research, 14(4),pp.595-602.

3. Januário $A$. L., Duarte W. R., Barriviera $M_{1}$, Mesti J. C., Araujo M. G., et al. (2011), "Dimension of the facial bone wall in the anterior maxilla: a cone-beam computedtomography study", Clin Oral Implants Res, 22(10), pp.1168-1171. 
4. Ghassemian M., Nowzari H., Lajolo $C_{.}$, Verdugo F., Pirronti T., et al. (2012), "Thethickness of facial alveolar bone overlying healthy maxillary anterior teeth", Periodontol,83(2), pp.187-197.

5. Januario A. L., Barriviera M., Duarte W. R. (2008), "Soft tissue cone-beam computed tomography: a novel method for the measurement of gingival tissue and the dimensions of the dentogingival unit", J Esthet Restor Dent, 20(6), pp.366-373.

6. Zekry A., Wang R., Chau A. C., Lang N.P.
(2012), "Facial alveolar bone wall width -a conebeam computed tomography study in Asians", Clin Oral Implants Res, 25(2),pp.194-206.

7. Grunder U., Gracis S., Capelli M. (2005), "Influence of the 3-D bone-to- implant relationship on esthetics", Int J Periodontics Restorative Dent, 25(2), pp.113-119.

8. Mandelaris G. A., Vence B. S., Rosenfeld A. L., Forbes D. P. (2013), "A classificationsystem for crestal and radicular dentoalveolar bone phenotypes", Int ] PeriodonticsRestorative Dent, 33(3), pp.289-296.

\section{KẾT QUẢ PHÂN TÍCH DƯớI NHÓM HÓA TRI VINORELBIN METRONOMIC UNG THƯ PHỔI KHÔNG TẾ BÀO NHỎ GIAI ĐOẠN TIẾN XA}

\section{TÓM TẮT}

Mục tiêu: Nghiên cứu nhằm đánh giá các yếu tố liên quan đến kết quả điều trị Vinorelbine Metronomic ung thư phổi không tế bào nhỏ giai đoan tiến xa. Đối tướng và phương pháp: Ung thư phổi không tế bào nhỏ tiến triển sau điều trị hóa chất bước 1 . Nghiên cứu hồi cứu. Điều tri: Vinorelbine uống mối lần $50 \mathrm{mg}$, tuần $2-3$ lần tùy thể trạng bệnh nhân và quyết định của thày thuốc Kết quả và kết luân: Kết quả điêu trị không khác biệt giữa các nhóm tuổi. Kết quả cao hơn ở những bênh nhân điều trị bước 2 so với điều trị từ bước 3; ECOG 0,1 so với ECOG >1.

Tư khóa: Vinorelbine metronomic, giai đoạn tiến xa, ung thư phổi không tế bào nhỏ

\section{SUMMARY}

RESULTS OF ANALYSIS SUBGROUPS OF NON-SMALL CELL LUNG CANCER TREATED WITH VINORELBINE METRONOMIC

Objective: To evaluate treatment result of subgroups of Advanced - stage Non - small cell Lung cancer treated by Vinorelbine Metronomic. Patients: Advanced - stage Non - small cell Lung cancer patients progressed after first - line chemotherapy. Method: Retrospective study. Patients were given Vinorelbine $50 \mathrm{mg}$ twice or 3 times a week. Results and Conclusion: Treatment results did not differ between age groups. Results were higher in patients on second - line treatment compared with treatment from third line; ECOG 0,1 vs ECOG > 1 .

Keywords: Vinorelbine metronomic, advanced stage, non - small cell lung cancer

\section{I. ĐĂT VẤN ĐỀ}

Điều tri ung thư phổi không tế bào nhỏ (UTPKTBN) giai đoạn tiến xa nhằm mục đích kéo

*Bệnh viện K trung ương

Chịu trách nhiệm chính: Nguyễn Thị Thái Hòa

Email: Bshoabvk@gmail.com

Ngày nhân bài: 10/2/2021

Ngày phản biên khoa hoc: 11/3/2021

Ngày duyệt bài: 25/3/2021
Nguyễn Thị Thái Hòa*

dài sống còn, giảm triệu chứng, nâng cao chất lượng sống cho người bệnh. Đây là một nhóm bệnh nhân có tiên lượng rất dè dặt với điều trị chủ đạo là các điều trị nội khoa ung thư kết hợp với chăm sóc giảm nhe. Với những hiểu biết gần đây về con đường dẫn truyền tín hiệu tế bào cũng như các chốt kiểm soát miễn dịch, nhiều thế hê thuốc đích và miễn dich đã đem lại hiêu quả cho nhiều người bệnh. Tuy nhiên, tại Việt nam phần lớn các bênh nhân vẫn điêu trị hóa chất từ bước 1 đến các bước sau. Khi đã thất bai với điều trị bước 1 , thể trang bênh nhân thường yếu, điêu trị phác đồ bộ đôi không còn thích hợp vì ít cải thiên hiêu quả và đôc tính cao. Hóa trị metronomic là môt cách thức điều trị khác biêt so với điều trị cổ điển, bởi được đưa vào cơ thể bởi các liêu nhỏ, liên tục. Ngoài tác dụng kháng u theo cơ chế như các hóa tri khác, điều trị metronomic còn có tác dụng chống tăng sinh mạch máu và thay đổi vi môi trường miễn dịch; từ đó nâng hiêu quả của điều trị với đôc tính tối thiểu $[1,2]$. Các nghiên cứu trên thế giới đã cho thây những kết quả đáng khích lệ của Vinorelbine Metronomic đối với UTPKTBN giai đoan tiến xa $[3,4]$. Nhằm có những phân tích sâu hơn về kết quả của điều trị này trên những nhóm bệnh nhân khác nhau, chúng tôi tiến hành đề tài này nhằm mục tiêu: "Đánh giá kết quả điều trị Vinorelbine metronomic đối với ung thư phổi không tế bào nhỏ giai đoạn tiến xa trên các phân nhóm bệnh nhân".

\section{II. ĐỐI TƯƠNG VÀ PHƯƠNG PHÁP NGHIÊN CỨU \\ 2.1. Đối tượng nghiên cứu}

Tiêu chuẩn chọn: Bệnh nhân được chẩn đoán là ung thư phổi không tế bào nhỏ giai đoạn IV, điều trị từ bước 2 bằng vinorelbine metronomic tại Bênh viên $K$ từ $1 / 2019$ đến 6/2020

Tiêu chuẩn loại: Di căn não 